DOI 10.18551/rjoas.2019-07.12

\title{
THE INFLUENCE OF FIRM CHARACTERISTICS, CORPORATE GOVERNANCE AND CAPITAL STRUCTURE ON ISLAMICITY DISCLOSURE INDEX: A STUDY OF COMPANIES LISTED IN JAKARTA ISLAMIC INDEX DURING PERIOD OF 2012-2016
}

\author{
Ferriswara Dian* \\ Doctoral Candidate, Doctoral Program of Business Administration, University of Brawijaya, \\ Malang, Indonesia \\ Suhadak, Professor \\ Handayani Siti Ragil, Rahayu Sri Mangesti, Lecturers \\ Doctoral Program of Business Administration, University of Brawijaya, Malang, Indonesia
}

*E-mail: dianfs@gmail.com

\begin{abstract}
The purpose of this study is to examine and explain the effect of Firm Characteristics, Corporate Governance and Capital Structure on the Islamicity Disclosure Index. This research is explanatory research to explain the causal relationship between research variables through hypothesis testing. The method of data analysis uses Generalized Structured Component Analysis (GSCA) analysis. Research findings in general, there are two variables that have a positive and significant effect on the Islamicity Disclosure Index, namely Firm Characteristics and Capital Structure. Corporate Governance variables have a positive and not significant effect on Islamicity Disclosure Index.
\end{abstract}

\section{KEY WORDS}

Firm characteristics, corporate governance, capital structure, Islamicity Disclosure Index.

The Phenomenon of the Islamic Capital Market has experienced rapid development for decades as part of the world financial market. The Islamic Capital Market has been implemented by capitalist countries such as the United States through the Dow Jones Islamic Market Index (DJIMI), the Dow Jones Islamic Average and the Shariah All World Financial Times Stock Exchange (FTSE); in addition, in India there are Bombay Stock Exchange TASIS Shariah 50 Index, Republic of Korea Shariah Security Policy International Board Market Index (SPGI BMI) in Korea; S \& P Japan 500 Shariah in Japan; Shariah China's Financial Times Stock Exchange (FTSE) in China; SPGI BMI Philippines Shariah in the Philippines and SPGI BMI Singapore Shariah in Singapore, SPGI Hong Kong Shariah in Hong Kong and several other Muslim minority countries (Hakim and Rashidian 2002).

Especially in the Sharia Capital Market in Indonesia, it was initiated by the launch of the Jakarta Islamic Index (JII) in 2000 by the Indonesia Stock Exchange (IDX) in collaboration with PT Danareksa Investment Management. The development of sharia shares included in the Jakarta Islamic Index (JII) continues to increase, this has led to sharia stocks themselves becoming increasingly attractive to investors. This shows that the company needs to improve the quality of corporate reporting, not only based on financial reports but also in terms of its Sharia reporting

The policy of disclosing information openly about the financial condition of this company is very important for public companies. This information disclosure can be used as a tangible manifestation of management transparency and accountability in managing the company to stakeholders. This information disclosure can be used as a consideration for stakeholders in decision making. Sharia Index disclosures are included in the category of voluntary disclosure used by management to increase the credibility of the company.

Many factors can influence the voluntary disclosure of company information, such as that carried out by Talpur, Lizam \& Keerio (2018) that found evidence that Firm 
Characteristics proxied by company size is a factor that influences in determining the level and quality of voluntary corporate governance disclosure practices. Furthermore, Abeywardana \& Panditharathna (2016) in their research found evidence that firm size and age are determinants of the level of voluntary disclosure of company information.

This voluntary disclosure of company information is a positive signal for the company. Signaling Theory (Ross, 1977) suggests that how a company should signal to the public. This signal is in the form of information about what has been done by management. signals can be in the form of promotions or other information that can state that the company has done better corporate governance than other companies.

The application of good corporate governance, company managers will always take appropriate and selfless actions, and can protect corporate stakeholders. According to Drever, signaling theory emphasizes that the reporting company can increase the value of the company through its reporting (Drever et al., 2007). This is in accordance with the Agency Theory (Jensen \& Meckling, 1976) and the results of the research by Aburaya (2012), Samaha et al. (2012) and Gao and Kling (2012) who found that good Corporate Governance will further enhance Firm Disclosure to parties outside the company.

Corporate governance is a set of rules that regulate relations between holders, managers of companies, creditors, governments, employees and other internal and external stakeholders who are related to their rights and obligations or in other words a system that controls the company. A good governance mechanism has been believed to be able to encourage companies to consider external costs in their operations, in this case is the company's income policy from outside parties reflected in the Company's Capital Structure.

Problems that arise with regard to funding needs, and the fulfillment of funding needs sourced from within the company have been used all, so there is no other choice but to use funds originating from outside the company, both from debt and by issuing new shares. If the fulfillment of funds from external sources prioritizes debt only, our dependence on external parties will increase and financial risk will increase. Conversely, if we only base on stocks, the cost will be very expensive.

Jensen \& Meckling (1976) connects agency cost with debt in the Capital Structure. Agency theory states that in determining the Capital Structure it is also necessary to consider the costs incurred due to differences in interests between the owner and the management of the company. Based on the Capital Structure theory has a positive effect on the possibility of bankruptcy, the value of liquidation, and the reputation of the manager. Capital Structure has a greater effect on the lender, so the cost of debt becomes bigger.

Based on Signaling Theory (Watson \& Marston, 2002), Capital Structure also influences the Islamicity Disclosure Index. If the company has a good Capital Structure and so that the company has a good impression, the company will disclose widely to the public regarding its existence. This is evidenced by the study of Craig and Diga (1998) which shows that Capital Structure has a significant and positive effect on Firm Disclosure.

Nguyen et al. (2017) in their study found that there was a positive influence between leverage as measured by the Long-term debt to total asset ratio (LTDTA) and the level of disclosure of environmental accounting information. This indicates that companies with larger amounts of long-term debt tend to have high levels of company disclosure and transparency.

Based on the results of several previous studies and existing theories, this study seeks to develop a more representative model of each variable identified as a variable that has an influence on disclosure of company information. Furthermore, the research aims to examine and explain the effect of Firm Characteristics, Corporate Governance and Capital Structure on the Islamicity Disclosure Index on Companies listed in the Jakarta Islamic Index.

\section{THEORETICAL FRAMEWORK AND HYPOTHESIS}

Firm Characteristics are conceptualized differently by various studies depending on the criteria used to define them. However, most studies seem to agree in the position that company characteristics are related to company resources and organizational goals. 
Wallace, Naser \& Mora (1994) defines Firm Characteristics as factors that distinguish companies. The factors that distinguish these include company size, company age, type of company, multinational or not, liquidity, profitability, leverage, social constraints that are owned, the owner's country of a company, the country where the company is, etc.

Lang \& Lungdholm divided Firm Characteristics into three categories (Wallace, Naser, \& Mora, 1994), namely:

- Structure-related variables are variables related to the structure, namely the economic condition of the company;

- Performance related variables are variables related to performance based on financial statements so that performance measurement is based on financial performance.

- Market related variables are a lot pointing to aspects of corporate behavior that arise as a result of participating as a member of a collaborative group between companies in an operational environment.

Wallace and Zinkin (2005) define Corporate Governance as "a set of provisions that enable the stockholders by exercising voting power to compel those in operating control of the firm to respect their interests", Manila's Asian Development Bank defines corporate governance as: "A set of rules that define the relationship between shareholders, managers, creditors, the government, employees and internal and external stakeholders in respect to their rights and responsibilities".

Corporate governance explains how the company should be directed and supervised, for example how to determine company goals and monitor performance related to the objectives that have been set. Good corporate governance will give a boost to the board and management to achieve goals, which are the interests of the company and its shareholders (Maier, 2005).

Riyanto (2001) explains that capital structure policy is part of the financing decision which is the main decision in financial management besides investment decisions and dividend decisions or dividend policies. Funding decisions involve decisions concerning the determination of the best funding sources or capital structure. The company's financing decision is one of the financial strategic decisions related to how the obtaining of funds and use of funds.

According to Gitman (2000) Capital Structure is the mix of long-term debt and equity maintained by the firm ". The Capital Structure describes the comparison between long-term debt and own capital used by the company. There are two types of capital according to Gitman, namely debt capital and equity.

The capital structure policy is part of the financing decision. Before discussing more about the theory of capital structure it is better if first understood what is actually meant by the term capital structure. Alwi (1993) states that capital structure is a comparison between long-term debt and own capital used by the company. Campsey \& Brigham (1985) introduced the notion of capital structure, namely: "capital structure is a percentage of each type of capital used by firm debt, preffered stock, and common equity".

Hameed et al. (2003) stated that the Islamicity Disclosure Index was developed to help stakeholders, namely shareholders, religious institutions, the government and other relevant parties to evaluate the performance of Islamic financial institutions. This approach basically aims to induce organizations to disclose further information, not only based on disclosure regulatory requirements according to regulatory requirements but based on what they must express. The Islamicity Disclosure Index is intended to examine how well the organization discloses information that might be useful to stakeholders.

The Islamicity Disclosure Index includes voluntary disclosure. Issuers registered in the Jakarta Islamic Index (JII) should be able to fulfill the Islamicity Disclosure Index. Islam has a message that is in line with the concept of corporate social responsibility. This is as concluded Kamla et al. (2006) that: "Islamic principles constitute a love of nature, and of people: the self and others, and awareness of the importance and balance of reasoning for actions to preserve this balance". It can be interpreted that Islamic principles are the love of nature, people (themselves and others) and awareness of the importance of balance and the 
need to take action to maintain that balance. The Islamicity Disclosure Index consists of sharia compliance index consisting of 14 items, corporate governance index consists of 35 items and social / environment index consists of 14 items.

Jensen and Meckling (1976) explain agency relations in agency theory that a company is a nexus of contracts between the principal and the agent who manages the use and control of these resources. Messier, et al. (2006) added that the agency relationship resulted in two problems, namely asymmetry information, where management generally had more information about the actual financial position and operating position of the entity than the owner; and conflict of interest due to inequality of objectives, where management (agent) does not always act according to the principal. Efforts to overcome or reduce agency problems will lead to agency costs borne by both the principal and the agent. Jensen and Meckling divided these agency costs into monitoring costs, bonding costs and residual losses. Monitoring costs are costs borne by the principal to monitor agent behavior, namely, to measure, observe, and control agent behavior. Bonding costs are costs borne by the agent to establish and comply with a mechanism that ensures that the agent will act in the interests of the principal. Furthermore, residual loss is a sacrifice in the form of reduced principal prosperity as a result of differences in agent decisions and principal decisions.

Morris (1987) states that the larger the company will have a greater agency cost so that it will reveal broader information to reduce agency costs. This is because the principal in overseeing the agent will be helped by stakeholders such as analysts, investors or the government who also give more attention to large-sized companies (Morris, 1987). Information presented can be used by other parties to control the activities of managers (Jensen \& Meckling, 1976).

Signaling theory arises due to the encouragement of companies to provide information to external parties due to the asymmetrical information that occurs in the company both financial information and non-financial information. Signal theory shows great consistency with broad disclosures, namely that companies that do not disclose good information mean that the company alienates itself from having a good impression, that is, being uninformative to the market regarding its existence (Kiswara, 1999). According to Drever et al. (2007), signaling theory emphasizes that the reporting company can increase the value of the company through its reporting. If the company fails to present more information, stakeholders will only rate the company as an average company with companies that do not disclose additional reports. This provides motivation for companies to disclose, through financial statements, that they are better than companies that do not make disclosures. Signaling theory emphasizes that companies will tend to provide more complete information to obtain a better reputation than companies that do not disclose, which in turn will attract investors.

Open disclosure of information about companies is very important for public companies. Information disclosure from the company can be used as a form of transparency and accountability of company management to stakeholders. Information disclosure from the company can be used as a consideration for stakeholders in decision making. Disclosure of information in annual reports can be grouped into two parts, namely: mandatory disclosure and voluntary disclosure. Mandatory disclosure is required disclosure by applicable regulations, while Voluntary disclosure is disclosure that is not required by regulations.

Sharia-based capital markets are developed with the aim of accommodating the needs of the majority of Muslims in Indonesia who have the desire to invest in capital market products in accordance with the basic principles of sharia. With the increasing diversity of facilities and investment products in Indonesia, it is expected that the community will have alternative investments that are considered to be in accordance with their wishes, in addition to investments that have been known and developed in the banking sector.

$\mathrm{JII}$ is an index of issuers whose business activities do not conflict with sharia, such as gambling businesses, conventional financial institutions (insurance and ribawi banks), production of illicit products and harm (damaging morals). Although there is a sharia screening process, in its operations the issuers in the Jll still do not operate in full sharia so that the implementation of the Islamic capital market is still not comprehensive (syariah) and syumul (perfect). The evaluation of the implementation of the Islamic capital market in 
Indonesia, especially at JII, still uses non-sharia concepts that are combined with the Islamic concept.

Many determinants that affect a company's financial performance and broad disclosure of company information. One of the factors that influence voluntary disclosure is the characteristics of the company. Stakeholder theory assumes that corporate accountability is not only related to improving economic or financial performance, but also related to performance in voluntarily disclosing information about business processes, corporate governance, intellectual, social and environmental performance. A report on disclosure of information will be useful for users, especially prospective investors if the information is presented in full so that it is easy to understand, relevant, reliable, and comparable.

Galani et al. (2011) in his research entitled The Association between Firm Characteristics and Corporate Mandatory Disclosure the Case of Greece found evidence that Firm Characteristics consisting of company size, profitability, age and type of industrial profile had a significant effect on company disclosures consisting of 100 items of disclosure based on the International Standards Committee.

Regarding financial decisions and managerial decisions, namely funding, investment decisions and disclosure of company information taken by company managers in order to improve company performance, one of the instruments used to control these decisions is corporate governance which is a structure, process, culture and system to create successful operational conditions for an organization.

Some empirical evidence has proven that Corporate Governance has a significant effect on the company's Financial Performance. Brown \& Caylor (2004) found evidence that the impact of implementing good corporate governance in addition to eliminating moral hazard and creating a healthier business climate also increased the confidence of investors and creditors. The application of good corporate governance will make investors give a positive response to Financial Performance. Effective corporate governance can increase the probability that managers invest in projects that have a positive net present value. Governed better companies have better performance. Gao \& King (2012) also found evidence that Corporate Governance consisting of external audit, internal governance and external governance had a significant effect on the fulfillment of company disclosures.

Agency Theory according to Jensen and Meckling (1976) bases the relationship between shareholders and managers. Differences in interests lead to information asymmetry (gap information) between the owner and manager of the company. Efficient capital markets must be able to provide protection to public investors from unhealthy, dishonest business practices and other forms of manipulation (Suta, 2000). Protection to public investors can be in the form of providing relevant information and facts about the company. Where information obtained from a company's financial statements depends on the level of disclosure of the financial statements in question. This study attempts to analyze the influence of issuers in JII that still operate conventionally non-religious on the extent of sharia disclosures disclosed by issuers.

Ross (1977) states that in the context of imperfect capital markets asymmetric information occurs due to the superiority of manager's knowledge of the company's prospects in the future, so asymmetric information based on the signaling hypothesis relates to funding decisions and financial policies on capital market conditions imperfect (transaction and tax costs) will affect the company's financial performance. Therefore, the company's financial performance is not only determined by optimal investment decisions but also by funding decisions (capital structure decisions).

Capital structure is very important for the company because it involves the policy of using the most profitable sources of funds. Sources of financing can be obtained from own capital and loan capital; therefore, the capital structure is one of the financial decisions related to achieving company goals. Financial managers must be able to improve the company's capital structure. This is intended to support the company in making decisions regarding the determination of funding sources to be used in managing the company's business. 
Jensen \& Meckling (1976) connects agency cost with debt contained in the Capital Structure. Agency theory says in determining the Capital Structure must consider the costs arising from debt interest, and the existence of differences in interests between the owner and the management of the company. Based on Agency theory, Capital Structure will have a positive effect on the possibility of the company experiencing bankruptcy, the value of liquidation, and the reputation of the manager. Capital Structure has a greater effect on the lender, so the cost of debt becomes bigger.

Chen (2009) found that Capital Structure in terms of company debt size had a significant and positive effect on disclosure of information disclosure in 1039 companies listed on the New York Stock Exchange (NYSE) for the period 1995-1999 and 2001-2005.

The findings above indicate that under the perfect capital market assumptions in reality it is very unlikely to occur so that in real world conditions that are imperfect capital markets (the existence of transaction costs, agency costs, and asymmetric information) the company's financial decisions will affect the breadth of disclosure of company information. Therefore, it is important to understand how financial policy factors decisions on capital structure, light-weight firm and corporate governance are primarily that can influence disclosure of company information.

This research is a development of the results of previous studies related to variables that are determinants of the interaction of firm characteristics, corporate governance, capital structure decisions with company financial performance and their impact on corporate information disclosure decisions. This research model was built on the basis of the development of previous research models based on the evolution of previous research models related to the variables under study. From the description above can be described the conceptual model in this study as shown in figure 1.

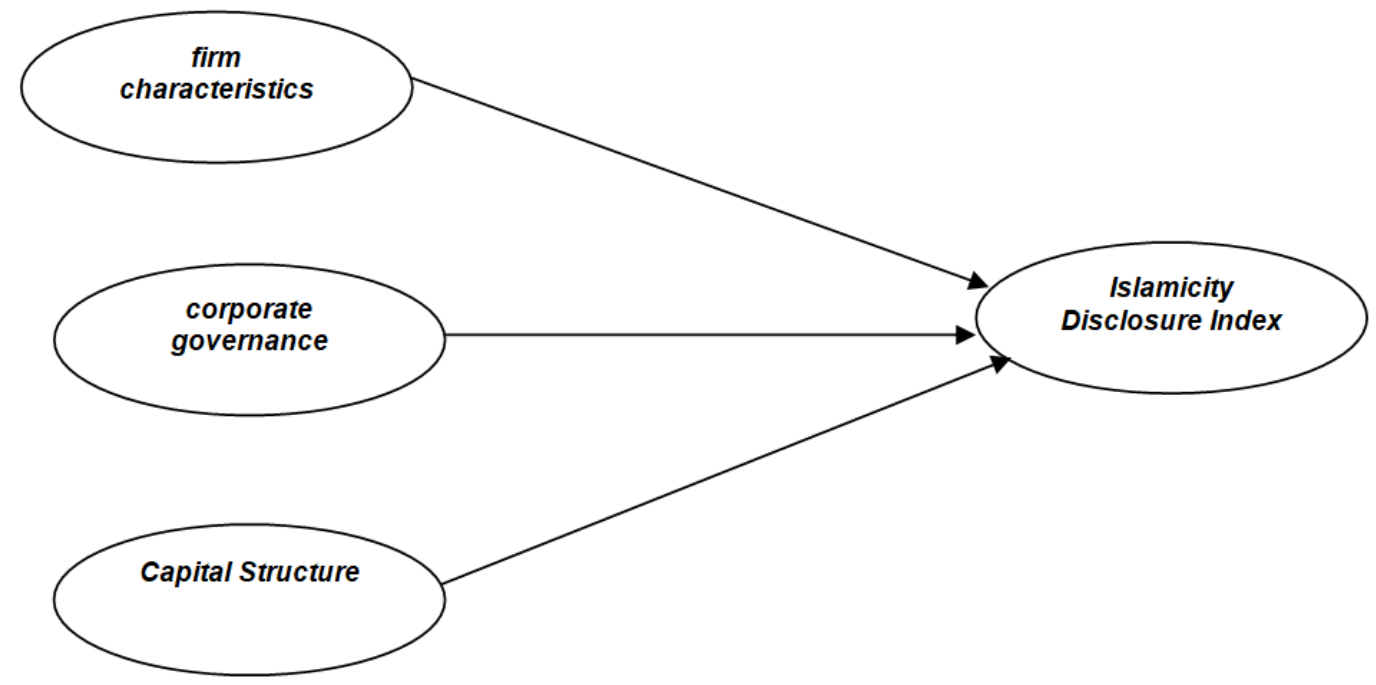

Figure 1 - Framework of Thinking

Based on stakeholder theory, Gray et al. (1995) the survival of a company depends on stakeholder support and that support must be sought so that the company's activities are to seek that support. One strategy to maintain relationships with stakeholders and company shareholders is to disclose financial and non-financial information that informs about economic, social and environmental performance as well as all company stakeholders. Corporate disclosure is expected to fulfill the wishes of stakeholders so that it will produce a harmonious relationship between the company and its stakeholders so that the company can achieve sustainability. This is reinforced by the opinion of Freeman \& McVea (2001) on Stakeholder Theory (Stakeholder Theory) which states that a company is not an entity that only operates for its own interests, but must provide benefits to its stakeholders (shareholders, creditors, consumers, suppliers, government, community, analysts and other 
parties). The more shareholders, this shows the more interested parties in the company, so the greater the pressure facing the company to disclose information.

Empirical research conducted by Bhayani (2012) in non-financial companies registered in the BSE 100 Index in the period 2008-2009 to 2010-2011 in India found that Firm Characteristics consisted of size, profitability, leverage, listing status, share ownership and company audits have a significant effect on company disclosures. Lucyanda \& Siagian (2012) also found that Firm Characteristics consisting of firm size, profitability, leverage, board of commissioner size, company profile, age, management ownership, earnings per share, environmental concern, and growth opportunities had a significant effect on disclosure of responsibility social company for companies listed on the Indonesian Stock Exchange for the period 2007-2008.

H1: Firm Characteristics has a significant effect on Islamicity Disclosure Index.

Agency Theory according to Jensen and Meckling (1976) bases the relationship between shareholders and managers. Differences in interests lead to information asymmetry (gap information) between the owner and manager of the company. The board of commissioners is a form of Corporate Governance where the board of commissioners is in charge of overseeing the performance of the board of directors / managers. Collier \& Gregory (1999) added that the greater the number of members of the board of commissioners, the more effective monitoring of the CEO will be. Furthermore, the more the board of commissioners in the company, the more contributions, suggestions and pressure on managers to disclose social responsibility as a liability of the company.

The representative of the principal in the company is the board of commissioners consisting of the main commissioners, commissioners and independent commissioners, which can influence the extent of social responsibility disclosure because the board of commissioners is the highest executor in the company. Furthermore, the existence of independent commissioners is important, because the greater the proportion of independent commissioners, the more effective the level of managerial oversight and then companies do more voluntary disclosure (Eng \& Mak, 2003).

Public ownership is also a part of Corporate Governance which is indicated to have an influence on company disclosures. According to Jensen and Meckling (1976) agency costs will increase along with the magnitude of the value of shares outstanding which is very closely related to the proportion of ownership to the company. To be able to reduce agency costs, wider disclosure of information is needed by company management. Therefore, companies with a majority of shares owned by the public will provide broader disclosures compared to companies whose shares are not owned by the public

Aburaya's (2012) research on American companies listed on the FTSE-All Share Index for the 2004-2007 period shows that Corporate Governance consists of board independence, board size, role duality, nomination committee independence, remuneration committee independence, community influence, cross -directorships, education, board meeting ownership structure, independence audit committee and institutional ownership have a significant effect on corporate environmental disclosures

Gao \& King (2012) also conducted research on the effect of Corporate Governance on disclosure. Research on companies in China registered with the Shenzhen Stock Exchange (SZSE) in the period 2001 to 2007 found that Corporate Governance consisting of external audits, internal governance and external governance had a significant effect on compliance with corporate disclosures.

H2: Corporate Governance has significant effect on Islamicity Disclosure Index.

Based on Signaling Theory, large companies have high needs for external funds such as debt and stocks, so companies have a greater incentive to signal the quality of the company through increased financial information disclosure (Marston, 2003).

Mollah, et al. (2000) state that companies with a large value of collateralizable assets (fixed assets) tend to use them to obtain large loans / debts, therefore Mollah, et al. (2000) assume that this type of asset also indicates the Capital Structure. Research conducted by Hossain \& Hammami (2009) on 25 companies listed on the Doha Securities Market (DSM) in 
Qatar in 2007-2008 found that age, size, complexity, and assets-in-place had a significant effect on company disclosures while profitability has no significant effect.

Furthermore, Ning Chen (2009) found that Capital Structure in terms of company debt size had a significant and positive effect on fair disclosure of company information disclosure in 1039 companies listed on the New York Stock Exchange (NYSE) in the period 1995-1999 and 2001-2005.

H3: Capital Structure has a significant effect on Islamicity Disclosure Index.

Table 1 - Hypotheses, Previous theoretical and research references in the Concept Model

\begin{tabular}{|l|l|l|}
\hline H & Hypotheses & Reference \\
\hline H1 & $\begin{array}{l}\text { Firm Characteristics has a significant } \\
\text { effect on Islamicity Disclosure Index }\end{array}$ & $\begin{array}{l}\text { Bhayani (2012), Lucyanda \& Siagian (2012), Kolsi (2012), } \\
\text { Soliman (2013), Talpur (2018), Galani et al. (2011) }\end{array}$ \\
\hline H2 & $\begin{array}{l}\text { Corporate Governance has a significant } \\
\text { effect on Islamicity Disclosure Index }\end{array}$ & $\begin{array}{l}\text { Aburaya (2012), Samaha et al. (2012), Gao and Kling (2012), } \\
\text { Attar (2016), Raithatha \& Bapat (2014), Affan et al. (2017), } \\
\text { Sepasi et al. (2016) }\end{array}$ \\
\hline H3 & $\begin{array}{l}\text { Capital Structure has a significant effect } \\
\text { on Islamicity Disclosure Index }\end{array}$ & $\begin{array}{l}\text { Craig dan Diga (1998), Nguyen et al. (2017), Connor dan Gao } \\
\text { (2011), Elfeky (2017) }\end{array}$ \\
\hline
\end{tabular}

Source: Data processed by the author.

\section{METHODS OF RESEARCH}

This study uses a quantitative approach to the type of explanatory research. Where the view of positivism is a quantitative basis and the search for linkages between research variables is a characteristic of explanatory research. Explanatory research is research conducted to explain causal relationships between research variables through hypothesis testing (Singarimbun \& Effendi, 2011). This study aims to test hypotheses from the influence of Firm Characteristics, Corporate Governance and Capital Structure variables on the Islamicity Disclosure Index.

The population in this study is the total number of issuers listed on the Index List of the Jakarta Islamic Index (JII). The total issuers for each period are 30 issuers taken from the List of Sharia Securities based on the largest number of market capitalization in each period

The Islamicity Disclosure Index is voluntary information disclosure in terms of fulfilling the Sharia Compliance Index, Corporate Governance Index and Social / Environment Index based on certain guidelines conducted by companies both Islamic companies and company's non-sharia for the benefit of related parties (Hameed et al., 2004).

According to Hameed et al (2004) the Islamicity Disclosure Index consists of the Sharia Compliance Index (14 indicators from 3 groups' indicator), Corporate Governance Index (35 indicators from 7 groups' indicator) and Social / Environment Index (14 indicators from 4 groups' indicator), presented in the table the following:

Table 2 - Measurement of Islamicity Disclosure Index

\begin{tabular}{|c|c|c|c|}
\hline No & Variable & Indicator & Measurement \\
\hline \multirow{3}{*}{1} & \multirow{3}{*}{$\begin{array}{l}\text { Islamicity } \\
\text { Disclosure } \\
\text { Index }\end{array}$} & $\begin{array}{l}\text { Sharia Compliance Index } \\
\text { (supervisory board, basic of information, financial } \\
\text { statement.) }\end{array}$ & \multirow{3}{*}{$\begin{array}{c}\text { Indeks }=\frac{n}{k} \times 100 \% \\
(\text { Hameed et al. 2003) } \\
\mathrm{n}=\text { number of items fulfilled } \\
\mathrm{k}=\text { total items that must be } \\
\text { fulfilled }\end{array}$} \\
\hline & & $\begin{array}{l}\text { Corporate Governance Index (composition of board of } \\
\text { directors, appointment, Board Meeting, Directors' fees and } \\
\text { remuneration, Nomination committee, Remuneration } \\
\text { Committee, Audit Committee, Sharia Supervisory, Others) }\end{array}$ & \\
\hline & & $\begin{array}{l}\text { Social/Environment Index } \\
\text { (Policy and objective, Community issues, Employees } \\
\text { issues, Environmental issues.) }\end{array}$ & \\
\hline
\end{tabular}


Table 3 - Measurement of Independent Variables

\begin{tabular}{|c|c|c|c|}
\hline No & Variable & indicator & Measurement \\
\hline \multirow{3}{*}{1} & \multirow{3}{*}{$\begin{array}{c}\text { Firm } \\
\text { Characteristics }\end{array}$} & Firm Size & Log natural total asset (Doan and Nguyen 2011) \\
\hline & & Firm Age & $\begin{array}{l}\text { The difference between the last year of the financial statements } \\
\text { for the year the company was established and the first to operate } \\
\text { (Elshabasy 2017; Soliman 2013; Talpur, Lizam, and Keerio } \\
\text { 2018) }\end{array}$ \\
\hline & & Firm List & $\begin{array}{c}\text { The latest year difference in financial statements against the } \\
\text { company's first listing year on the stock exchange (Talpur, } \\
\text { Lizam, and Keerio 2018) }\end{array}$ \\
\hline \multirow{4}{*}{2} & \multirow{4}{*}{$\begin{array}{c}\text { Corporate } \\
\text { Governance }\end{array}$} & $\begin{array}{c}\text { Independent Board } \\
\text { Members }\end{array}$ & $I B M=\frac{\text { Number of Independent Commissioners }}{\text { Total of Independent Commissioner }} \times 100 \%$ \\
\hline & & $\begin{array}{l}\text { Managerial } \\
\text { Ownership }\end{array}$ & $M O=\frac{\sum \text { shares owned by management }}{\sum \begin{array}{c}\text { outstanding company shares } \\
\text { (Iturriaga and Sanz 2001) }\end{array}} \times 100 \%$ \\
\hline & & $\begin{array}{l}\text { Institutional } \\
\text { Ownership }\end{array}$ & $I O=\frac{\sum \text { institutional shares }}{\sum \begin{array}{l}\text { outstanding company shares } \\
(\text { Shen, Hsu, and Chen 2006) }\end{array}} \times 100 \%$ \\
\hline & & Public Ownership & $P O=\frac{\sum \text { public owned shares }}{\sum \text { outstanding company shares }} \times 100 \%$ \\
\hline \multirow{5}{*}{3} & \multirow{5}{*}{ Capital Structure } & $\begin{array}{l}\text { Long Term Debt to } \\
\text { Total Asset ratio } \\
\quad \text { (LTDTA) }\end{array}$ & $\begin{array}{c}\qquad \text { LTDT } A=\frac{\text { Long }- \text { term debt }}{\text { Total Aset }} \times 100 \% \\
(\text { Khan, Niazi, and Akram 2013; Khanam, Nasreen, and Pirzada } \\
\text { 2014; Marobhe 2014) }\end{array}$ \\
\hline & & $\begin{array}{l}\text { Long Term Debt to } \\
\text { Total Equity ratio } \\
\quad \text { (LTDTE) }\end{array}$ & $\begin{array}{l}\text { LTDTE }=\frac{\text { Long }- \text { term debt }}{\text { Total Equity }} \times 100 \% \\
(\text { Abdul Rahman 2017) }\end{array}$ \\
\hline & & Debt Ratio & $\begin{array}{c}D R=\frac{\text { Total Debt }}{\text { Total Asets }} \times 100 \% \\
\text { (Jain, Shekhar, and Torbey 2003) }\end{array}$ \\
\hline & & Debt to Equity & $\begin{array}{c}D E=\frac{\text { Total Debt }}{\text { Total Equity }} \times 100 \% \\
(\text { Van Horne and Wachowicz 1997) }\end{array}$ \\
\hline & & $\begin{array}{c}\text { Collateralizable } \\
\text { Assets }\end{array}$ & $\begin{array}{c}C A=\frac{\text { Fixed Assets }}{\text { Total Assets }} \times 100 \% \\
(\text { Mollah, Kevin, and Helen 2000) }\end{array}$ \\
\hline
\end{tabular}

The steps in the GeSCA are as follows (Solimun, 2013):

- Designing a Structural Model (relationship between latent variables). The design of the structural model of relations between latent variables on GSCA is based on the formulation of the problem or research hypothesis;

- Designing a Measurement Model. Designing the measurement model referred to in the GSCA is determining the nature of the indicators of each latent variable, whether reflexive or formative. Errors in determining this measurement model will be serious, which is to provide biased analysis results. The basis can be used as a reference to determine the nature of indicators whether reflexive or formative are: normative finality, theory, previous empirical research, or if it is not there, it is rational;

- Constructing the Path diagram. When steps one and two have been done, so that the results are easier to understand, the design results are then stated in the form of a path diagram. An example of a path diagram for GSCA can be seen in Figure 2. Research Analysis Model. 


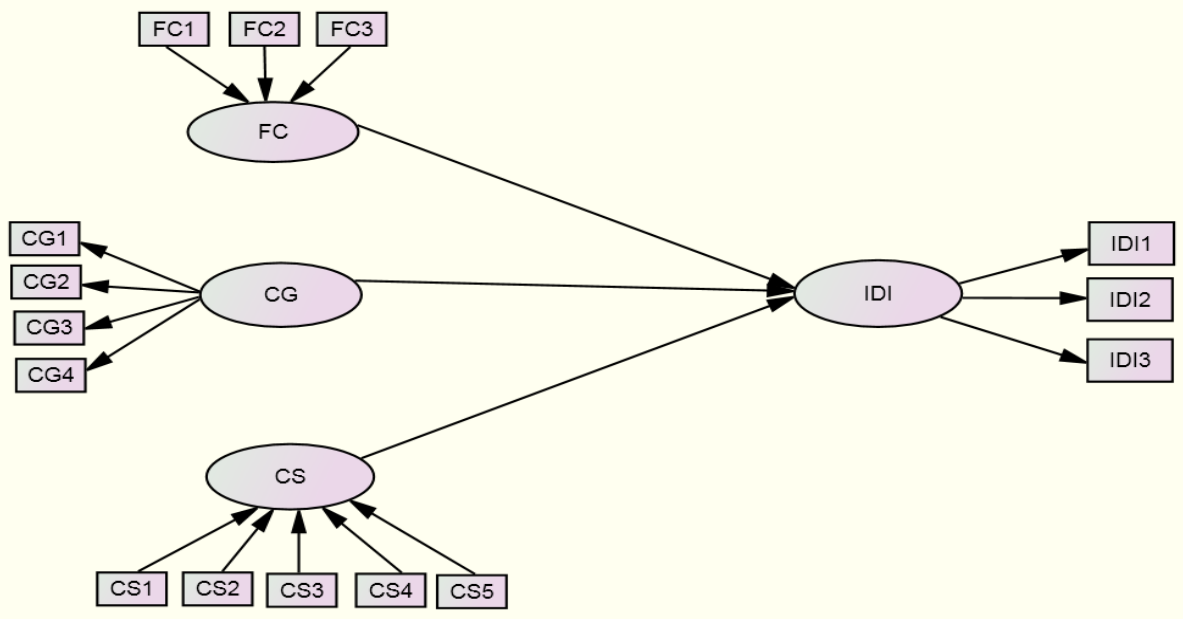

Figure 2 - Research Analysis Model

$\begin{array}{llll}\text { FC: Firm Characteristics } & \text { CG: Corporate Governance } & \text { CS: Capital Structure } & \text { IDI: Islamicity Disclosure Index } \\ \text { FC1: Firm Size } & \text { CG1: Independent Board } & \text { CS1: Long Term Debt to Total Asset ratio } & \text { IDI1: Sharia Compliance Index } \\ \text { FC2: Firm Age } & \text { Members } & \text { CS2: Long Term Debt to Total Equity } & \text { IDI2: Corporate Governance } \\ \text { FC3: Firm List } & \text { CG2: Managerial Ownership } & \text { CS3: Debt Ratio } & \text { Index } \\ & \text { CG3: Institutional Ownership } & \text { CS4: Debt to Equity Ratio } & \text { IDI3: Social/ Environment } \\ & \text { CG4: Public Ownership } & \text { CS5: Collateralizable Assets } & \text { Index }\end{array}$

Goodness of Fit Structural Model is measured using FIT, namely; equivalent to RSquare in regression analysis or total determination coefficient in path analysis or 02.

a. FIT Shows the total variance of all variables which can be explained by the structural model, the FIT value ranges from 0 to 1 , the greater the variance of variable variances that can be explained by the model. If the value of FIT $=1$ means the model can perfectly explain the phenomenon under investigation.

b. AFIT (Adjusted FIT) similar to R2 adjusted in regression analysis, AFIT can be used for comparison of models. The model with the greatest value of AFIT can be chosen between better models (Solimun, 2012).

\section{RESULTS AND DISCUSSION}

Overall Model Testing involving measurement models and structural models based on GSCA calculations and significant tests obtained through Boststrapping which can be seen in table 4 below:

Table 4 - Testing of Fit Models

\begin{tabular}{|c|c|}
\hline & Model Fit \\
\hline FIT & 0.374 \\
\hline AFIT & 0.371 \\
\hline NPAR & 34 \\
\hline
\end{tabular}

Table 5 - Results of Hypothesis Testing Analysis

\begin{tabular}{|c|c|c|c|c|c|}
\hline \multicolumn{7}{|c|}{ Effect Testing } & Estimate & $C R$ & explanation \\
\hline \multirow{2}{*}{ No } & $\begin{array}{c}\text { Relationship between Variables } \\
\text { (Explanatory variable } \rightarrow \text { Response variable) }\end{array}$ & Islamicity Disclosure Index & 0,729 & $15,47^{*}$ & Significant \\
\hline 1 & Firm Characteristics & Islamicity Disclosure Index & 0,034 & 0,54 & Non Significant \\
\hline 2 & Corporate Governance & Islamicity Disclosure Index & 0,408 & $2,22^{*}$ & Significant \\
\hline 3 & Capital Structure & Isture
\end{tabular}

Description: * Significant at $\alpha=0.05$.

The results of the analysis show that the FIT value is 0.374 , this means that the model formed is able to explain all existing variables by $37.4 \%$. The AFIT value $=0.371$ shows the diversity of Firm Characteristics, Corporate Governance, and Capital Structucre variables 
towards the Islamicity Disclosure Index which can be explained by the model after a correction of $37.1 \%$. Testing the hypothesis on GSCA analysis is based on the estimate value and significance between variables.

Hypothesis analysis results:

Hypothesis 1: Firm Characteristics has a significant effect on Islamicity Disclosure Index. The results of the GSCA test show that the path coefficient estimates are 0.729 and CR 15.47 is greater than t table 1.98, at the level of $P=0.05$. Empirical test results are enough evidence to accept the hypothesis 1 . Significant positive path coefficients can be interpreted between Firm Characteristics and the Islamicity Disclosure Index having a direct influence. The effect of Firm Characteristics on the Islamicity Disclosure Index is in accordance with the original prediction that Firm Characteristics has an effect on the Islamicity Disclosure Index. These results indicate that Firm Characteristics is a determining factor for the Islamicity Disclosure Index

Hypothesis 2: Corporate Governance has a significant effect on Islamicity Disclosure Index. The results of the GSCA test show that the path coefficient estimation is 0.034 and CR 0.54 is smaller than t table 1.98, at the level of $P=0.05$. Empirical test results are not enough evidence to accept the hypothesis 2 . The path coefficient marked positive is not significant, it can be interpreted that between Corporate Governance and Islamicity Disclosure Index has a direct influence. The influence of Corporate Governance on Islamicity Disclosure Index contradicts the original prediction that Corporate Governance has a significant effect on Islamicity Disclosure Index. These results indicate that Corporate Governance is not a determinant of Islamicity Disclosure Index

Hypothesis 3: Capital Structure has a significant effect on Islamicity Disclosure Index. The results of the GSCA test show that the path coefficient estimation is 0.408 and CR 2.22 is greater than t table 1.98, at the level of $P=0.05$. Empirical test results are sufficient evidence to accept hypotheses 3. Significant positive path coefficients can be interpreted that between Capital Structure and Islamicity Disclosure Index have a direct influence. The effect of Capital Structure on Islamicity Disclosure Index is the same as the initial prediction that Capital Structure has a significant effect on Islamicity Disclosure Index. These results indicate that Capital Structure is a determining factor for Islamicity Disclosure Index

\section{DISCUSSION OF RESULTS}

The Effect of Firm Characteristics on Islamicity Disclosure Index. Firm Characteristics variables have a significant influence on the Islamicity Disclosure Index. This finding is in accordance with the hypothesis prediction $(\mathrm{H} 1)$ which predicts that Firm Characteristics has a significant effect on the Islamicity Disclosure Index. The meaning of these findings shows that empirically Firm Characteristics is a factor that determines the company's Islamicity Disclosure Index included in the Jakarta Islamic Index group. This finding also indicates that the Islamicity Disclosure Index in companies belonging to the Jakarta Islamic Index in Indonesia is determined by the Firm Characteristics structure variable which consists of company size, company age and age of company listing on the stock market

The results of this study are in accordance with the research conducted by Galani et al. (2011) in 43 companies listed on the Athens Stock Exchange in Greece in Greece which found that Firm Characteristics consisting of company size, profitability, age and type of industry profile had a significant effect on corporate disclosure consisting of 100 disclosure items based on the International Standards Committee. Ikpor et al. (2016) stated that company size significantly affected the voluntary level of information disclosure disclosed in annual reports and bank accounts in Nigeria.

Large companies have a greater tendency to provide better disclosure transparency than small companies because this company has more financial and non-financial resources to support the disclosure. Company size is a scale that functions in classifying the size of a business entity. The size of the company will be able to influence the extent to which the information disclosure policy owned by the company. Large-scale companies will have a tendency to reveal more information owned by companies on a smaller scale. This is due to 
the fact that companies in the large-scale category will face greater risks than small companies.

Abeywardana \& Panditharathna (2016) in his research showed that firm size, profitability, firm age, leverage and board independence as determinants of voluntary disclosure levels and among them company size, profitability and age of the company had a positive relationship the leverage and board independence had a negative relationship. Voluntary disclosure of information on Corporate Governance, environmental and social performance, and the company's business processes is carried out to increase investor confidence. The results of this study are in accordance with stakeholder theory which explains that the age of a company is an indicator that the company exists and can compete. Older companies will have in-depth knowledge about how they should act in providing information about companies to outsiders, therefore, companies that have long operated with older ages will have a tendency to disclose complete information, including Corporate disclosures. Governance, environmental and social performance, and business processes, because the complete information disclosed in detail will provide added value to stakeholders and potential investors.

Nguyen et al. (2017) find evidence that Firm List influences the level of disclosure of the accountant's information environment. The age of the company's listing is the age of the company which is calculated based on the date of the IPO (Initial Public Offering) of the company. The longer the age of the company listing, the company will tend to disclose its information more broadly. Owusu-Ansah (1998) provides three reasons, first, younger companies will experience competitive losses if they disclose information such as research costs, capital costs and product development. Second, the costs of disclosing information such as the costs of gathering, processing and disseminating information, may be burdensome to younger companies. Third, younger companies do not have experience or track record in disclosing information.

The results of the study are in line with the findings of Talpur (2018) which states that the practice of disclosure of voluntary corporate governance among companies listed on Malaysian property increased by a significant percentage. Companies listed on property are motivated to disclose this information for the benefit of shareholders. On the other hand, the larger the company, the higher the level of disclosure, large companies have more interest in disclosing additional information compared to small companies. Firm size as a factor that influences the level and quality of voluntary disclosure of corporate governance practices.

The Effect of Corporate Governance on Islamicity Disclosure Index. The Corporate Governance variable has a non-significant effect on the Islamicity Disclosure Index. This finding contrasts with the hypothesis prediction $(\mathrm{H} 2)$ which predicts that Corporate Governance has a significant effect on the Islamicity Disclosure Index. The meaning of these findings shows that empirically Corporate Governance has no significant effect on the Islamicity Disclosure Index, meaning that it is not a determining factor in the company's Islamicity Disclosure Index listed in the Jakarta Islamic Index in Indonesia. This finding also indicates that the Islamicity Disclosure Index in companies listed in the Jakarta Islamic Index in Indonesia is not always determined by the Independent Board Members, Managerial Ownership, Institutional Ownership and Public Ownership variables.

The direction of the path coefficient of Corporate Governance that is positively insignificant does not support the research concept of Samaha Khaled (2010), Raithatha \& Bapat (2014) which shows that good Corporate Governance will further increase Firm Disclosure. The director, as the leading position, is very important and is the key to the company's success. This finding also explains that although the proportion of independent commissioners is higher than required, independent commissioners cannot function properly. This is more due to the procedure for selecting the board of commissioners. In Indonesia, the board of commissioners is generally set only as a formality to comply with the rules. Members are not independent and lack adequate competence. This is a common phenomenon in Indonesia that a government official or former government official is chosen as a member of the commissioner because it hopes to be able to help the company to gain access to government institutions more easily. 
Theoretically, the Board of Commissioners is a part of the company that has the task of overseeing the performance of the Board of Directors in carrying out management functions in the company. When carrying out its supervisory role, the effectiveness of the supervisory function will be hindered if at the same time members of the Board of Commissioners participate in management in the company. the transfer of wealth from minority shareholders to the controlling shareholders will occur due to cooperation between management and the Board of Commissioners. In order to reduce these risks, the Board of Commissioners needs to be held by independent parties, in agency theory this is one way to maintain the functions of the Board of Commissioners in order to remain independent in structural management.

The direction of the path coefficient of Corporate Governance which is positively insignificant does not support the research concept of Affan et al. (2017) states that institutional ownership has a significant influence on the quality of disclosure of corporate financial information. Institutional ownership has an influence on monitoring the behavior of company managers. The influence of the level of supervision by institutional shareholders in this study is based on the average share ownership by the company held by institutional shareholders, so that gaps can be minimized which will automatically reduce opportunistic actions.

The low percentage of managerial ownership and the dominance of institutional ownership in the shareholding structure of companies classified as $\mathrm{JII}$ in Indonesia, this also shows that there is no clear separation between ownership and control of the company and this condition results in the majority of companies still being controlled by shareholders the majority is through a corporate legal entity or holding company so that the management of the company is still under control or an extension of the majority shareholder controlled by the founding family or certain. Second, the empirical conditions in the capital market in Indonesia which are still emerging markets have historically had a background and the existence of different cultures with empirical conditions on the capital market in developed countries where the agency theory was built.

The dominance of institutional ownership in the ownership structure of companies classified as JII in Indonesia, empirically has insignificant influence on disclosure of company information. This indicates that the role of managerial ownership is still weak and institutional ownership does not act as an effective monitoring agent as expected and this finding also indicates that the role of the distribution of ownership or the number of ordinary holders in JII companies in Indonesia is still weak in optimally monitoring the company. The results of this study also indicate that in the capital market that is still an emerging market, it shows that the institutional ownership structure has a negative effect on disclosure of company information. The dominance of institutional ownership in the ownership structure of the company that is the sample of this study indicates that there is still a concentration of company ownership in the ownership structure of the company which is a sample of institutional ownership.

The greater the ratio of shares held by the public, the greater the likelihood that the company will disclose information in the annual report. The greater the share of shares held by the public; the more parties will need information about the company so that there will be more extensive disclosure of company information demanded in the annual report. The more shares owned by the public or the community, the more people will control the development of the company. So, the company will have a broader tendency to disclose its company information. However, it should also be remembered that the Islamicity Disclosure Index is included in the type of voluntary disclosure so that issuers listed in the Jakarta Islamic Index (JII) are not required to meet the Islamicity Disclosure Index.

The Effect Capital Structure on Islamicity Disclosure Index. Capital structure variables have a significant influence on the Islamicity Disclosure Index. This finding is in accordance with hypothesis prediction $(\mathrm{H} 3)$ which predicts that Capital Structure has a significant effect on the Islamicity Disclosure Index. The meaning of these findings shows that empirically the capital structure is a determining factor in the company's Islamicity Disclosure Index, which includes $\mathrm{JII}$ in Indonesia. This finding also indicates that the decision to disclose the Islamic Disclosure Index on companies included in the $\mathrm{JII}$ in Indonesia is determined by capital structure variables. 
Capital structure is a comparison between long-term debt to own capital. Fulfillment of company funding needs can come from own capital, share capital, retained earnings and profit reserves. If the company uses capital derived from its own capital is still lacking (deficit), then management needs to consider funding from outside the company, namely from debt (debt financing). In the selection of capital structure management, company management must first determine a profitable way of choosing funding so that the company's survival is guaranteed. The choice of form and type of fund must pay attention to the purpose of using the fund, if the funds are used to meet short-term needs, the investment should be funded with short-term funding sources. While the funds used for long-term investments, the company must use long-term funding sources.

The direction of the path coefficient of capital structure is positive, this indicates that the capital structure has a positive and significant effect on the Islamicity Disclosure Index. The meaning of these findings shows that increasing the use of debt in the capital structure will increase the Islamicity Disclosure Index. on companies included in JII in Indonesia. This is because the use of debt in the company's capital structure in the companies included in the $\mathrm{JII}$ in Indonesia provides benefits, namely the tax savings from interest payments. Nguyen et al. (2017) in his research found that there was a positive influence between leverage as measured by the Long-term debt to total asset ratio (LTDTA) and the level of disclosure of environmental accounting information. This indicates that companies with larger amounts of long-term debt tend to have high levels of company disclosure and transparency.

The higher the level of corporate leverage, the greater the agency cost or in other words the greater the likelihood of the prosperity transfer from long-term creditors to shareholders and managers so that the company is required to make more complete disclosures to meet the information needs of creditors. long-term. The company's dependence on debt in financing its operations is reflected in leverage, as an illustration of the company's capital structure, so that the level of risk of uncollectible debt can be seen. Through leverage measured using long-term debt to total assets will provide a relatively long time for the company to pay its obligations. High level of leverage will tend to do more disclosure of company information, because the management will try to explain why the level of corporate debt tends to be high.

Elfeky (2017) in his research found that there was a positive influence between leverage measured by LTDER and the level of voluntary disclosure of company information. This indicates that companies with a greater amount of long-term debt to equity tend to have high and transparent levels of corporate disclosure. Companies that earn profits from longterm debt to capital increase, the capital will be obtained more from debt. So, by increasing the use of long-term debt to capital, the use of debt will increase the company's loan capital, thereby increasing profits will affect the increase in debt to the company because creditors will be interested in providing loans to companies because they see a high level of profit. This condition will cause management to tend to disclose company information more, because management will try to explain why the company uses long-term debt.

Furthermore Semper \& Beltran (2014) shows that leverage measured by Debt to Equity Ratio has a significant influence on risk disclosure and risk factor index. Market conditions require companies to disclose more information about risks so that large information disclosures will lead to higher equity costs. The leverage ratio shows the extent to which the assets of the company are financed by borrowing debt. A high leverage ratio indicates that the company gets funding from investors or creditors outside the company. The higher the leverage ratio means the greater the proportion of corporate funding obtained from debt. Agency signal theory predicts that companies that have higher leverage ratios will disclose more information because of demands from investors who have invested their shares, this is done to provide oversight of every management action in managing the funds and facilities provided by investors.

Baimukhamedova \& Baimukhamedova (2015) in their study found that there was a positive influence between leverage measured by the ratio of total liabilities to total assets and the level of information disclosure. This indicates that companies with a larger amount of debt tend to have a high level of corporate disclosure and transparency. Debt consists of 
current (short-term) and long-term liabilities. Creditors will like a low debt ratio because with low debt there will be enough reserve funds for creditors if there is liquidation at the company. But for company owners, high debt ratios will be able to double profits or profits and also reduce control of the company. In connection with signaling theory, management needs to signal that the composition of total debt with total assets is still in the safe category, meaning that the company still gets a high profit compared to the cost of debt that must be incurred. Management's consideration in disclosing information voluntarily will be affected by the presence of agency costs and benefits. Management will disclose information in full if the disclosure of information has substantial benefits compared to the costs spent. This information is a signal to the public that the company has prospects in the future.

The company's capital structure will be related to the consideration of the costs and benefits of using funds through debt and equity (Myers 1984). In order to fulfill the goal of maximizing profit for shareholders realized by maximizing the value of the company, it will not materialize if the company has a capital structure with high debt. The composition of the capital structure owned by the company will have an impact on the company's financial condition. The optimal capital structure in the company will provide shareholder benefits. Increasing the source of funds through debt will increase the amount of interest the company must pay. Increasing the level of debt also indicates the inability of companies to minimize the risk of liquidation. This condition will make investors rethink if they will invest in the company.

Balakrishnan, Core, \& Verdi (2014) show that Collateralizable Assets that are high in the structure of assets used by collateral will cause wider disclosure of information. Large real estate companies with high collateral ownership in fixed assets will disclose their financial statement information more broadly to make it easier to obtain financing. Company asset structure will have a direct impact on capital structure because the structure of assets in the company is a guarantee when the company borrows money from creditors to increase its debt. Based on the theory of information asymmetry (Chen and Strange, 1998), the structure of assets in the company has a direct impact on capital structure considering the company's asset structure can be used as collateral when the company borrows money from creditors to increase its debt, when creditors do not have extensive and extensive information regarding the behavior of the company's capital structure, the company that has a little asset structure will find it difficult to get funds from investors, thus the company needs to disclose complete information about the condition of its asset structure.

Collateralizable assets are assets that can be guaranteed to creditors to guarantee corporate loans. Titman and Wessels (1988) state that companies that have more collateral assets have a smaller agency problem between creditors and shareholders because such assets can function as collateral for debt. Given that collateralizable assets function to reduce agency problems, it is expected that the amount of collateralizable assets owned by the company will have a positive effect on dividends. Assets guarantees are company assets that can be used as collateral for creditors. Creditors often pay attention to the amount of collateral in the form of assets when lending to a company. If the company has a large asset guarantee, then this is good news as a signal that the company has the ability to guarantee debt.

\section{CONCLUSION}

Firm Characteristics measured by Firm Size and Firm Age have a significant influence with Islamicity Disclosure Index. This finding is in line with the research concepts of Nguyen et. Al (2017), Talpur (2018), Abeywardhana (2016), Soliman (2013), and Galani et al. (2011) which states that Firm Characteristics consists of firm size, firm age and firm list affecting disclosure of company information. This finding indicates that Firm Characteristics empirically is a determining factor for Islamicity Disclosure Index in companies included in $\mathrm{JII}$ that are listed on the Indonesia Stock Exchange (IDX).

Corporate Governance as measured by Independent Board Members, Managerial Ownership, Institutional Ownership, and Public Ownership have a non-significant effect on 
Islamicity Disclosure Index. The direction of this insignificant influence is the finding of this study. This finding is an anomaly that occurs in companies included in the JII listing on the IDX and this finding is not in line with the research concept of Samaha et al. (2012), Gao and Kling (2012), Affan et al. (2017), and Sepasi et al. (2016.) which states that good Corporate Governance will increase Firm Disclosure to parties outside the company, internal governance leads to higher compliance with disclosure requirements, Ownership structure has an influence on monitoring the behavior of company managers and Agents are required to provide periodic information reports on the principal about the business processes that are implemented. Principals will provide an assessment of the performance of their agents through the disclosure or reporting of information submitted therefore, disclosure of company information is a means of management accountability to its owners

Capital Structure has a significant effect on Islamicity Disclosure Index with the direction of positive coefficient, which indicates that the use of debt in the company's capital structure in the companies included in the $\mathrm{JII}$ in Indonesia, this finding supports the research concept. Nguyen et al. (2017) Elfeky (2017), Semper \& Beltran (2014), Balakrishnan, Core, \& Verdi (2014) which states that companies with larger amounts of long-term debt tend to have high levels of company disclosure and transparency, market conditions require companies disclose more information about risks so that large information disclosures will lead to higher costs of equity, collateralizable assets that are high in the structure of assets used by collateral will lead to wider disclosure of information

\section{RECOMMENDATIONS}

The results showed that the Corporate Governance variables as measured by Independent Board Members, Managerial Ownership, Institutional Ownership, and Public Ownership had insignificant effects on the Islamicity Disclosure Index. This insignificant effect of Corporate Governance occurs due to the still low managerial ownership and the dominance of institutional ownership in the ownership structure of the company. This finding shows that empirically the structure of Corporate Governance is not a determining factor in the disclosure of corporate sharia information. Based on the results of this study, the suggestions that can be given to companies that are included in the JII listing on the IDX are that the spread of equitable share ownership is needed, not concentrated in institutional ownership, this is needed so that the decisions issued by company management prioritize the interests of the overall shareholders. Besides that, to avoid practices that harm minority shareholders (public shareholders).

Recommendations for the development of this research in the future are related to the substance of the study, namely adding qualitative external factors such as socio-political conditions, security, culture, legal certainty, capital market regulation, and technology and government policies relating to financial performance.

\section{REFERENCES}

1. Abeywardana, N. L. E., \& Panditharathna, K. M. (2016). The Extent and Determinants of Voluntary Disclosures in Annual Reports: Evidence from Banking and Finance Companies in Sri Lanka. In Accounting and Finance Research (Vol. 5, pp. 147-162). http://doi.org/10.1103/PhysRevE.59.4434

2. Aburaya, R. K. (2012). The Relationship between Corporate Governance and Environmental Disclosure: UK Evidence

3. Affan, M. W., Rosidi, \& Purwanti, L. (2017). The Effect of Ownership Structure on the Quality of Financial Reporting Of Manufacturing Companies Listed In the IDX during the Period of 2013-2015. Imperial Journal of Interdisciplinary Research (IJIR), 3(7), 165-174

4. Akhtaruddin, Mohamed, Monirul Alam Hossain, Mahmud Hossain, and Lee Yao. 2009. "Corporate Governance and Voluntary Disclosure in Corporate Annual Reports of Malaysian Listed Firms." JAMAR 7(1): 1-20.

5. Alwi. (1993). Alat-alat Analisis dalam Pembelanjaan. Yogyakarta: Andi Offset. 
6. Al Attar, M. K. (2016). Corporate Governance and Financial Statement Disclosure Quality in Jordanian Commercial Banks. International Journal of Economics and Finance, 8(10), 192-205. http://doi.org/10.5539/ijef.v8n10p192

7. Baimukhamedova, G., \& Baimukhamedova, A. (2015). The Effect of Corporate Governance on Companies' Earnings Management: Empirical Study of Kazakhstan Companies in Natural Resources Sector. International Journal of Research in Applied, Natural and Social Sciences, 3(10), 139-156.

8. Bhayani, S. (2012). Association between Firm-Specific Characteristics and Corporate Disclosure: The Case of India. In International Conference on Business, Economics, Management and Behavioral Sciences (ICBEMBS'2012) (pp. 8-11). Dubai

9. Balakrishnan, K., Core, J. E., \& Verdi, R. S. (2014). The Relation between Reporting Quality and Financing and Investment: Evidence from Changes in Financing Capacity. Journal of Accounting Research, 52(1), 1-36. Retrieved from http://papers.ssrn.com/sol3/papers.cfm?abstract_id=1932349

10. Brown, L. D., \& Caylor, M. L. (2004). Corporate Governance and Firm Performance. SSRN Electronic Journal. http://doi.org/10.2139/ssrn.586423

11. Campsey, B. J., \& Brigham, E. F. (1985). Introduction to Financial Management. New York: The Dryden Press

12. Chen, \& Dhiensiri. (2009). Determinants of Dividend Policy: The Evidence from New Zealand. International Research Journal of Finance Economics, 34.

13. Craig, R., \& Diga, J. (1998). Corporate Accounting Disclosure in ASEAN. Journal of International Financial Management and Accounting, 9(3), 246-274. http://doi.org/10.1111/1467-646X.00039

14. Collier, P., \& Gregory, A. (1999). Audit Committee Activity and Agency Costs. Journal of Accounting and Public Policy, 18(4-5), 311-332. http://doi.org/10.1016/S02784254(99)00015-0

15. Connors, E., \& Gao, L. S. (2011). Corporate Environmental Performance, Disclosure and Leverage: An Integrated Approach. International Review of Accounting, Banking and Finance, 3(3), 1-26

16. Drever, M., Stanton, Patricia Anne McGowan, S., Raar, J., Sofocleous, S., \& Ravlic, T. (2007). Contemporary issues in accounting. (P. A. Stanton, S. (Susan C.. McGowan, J. Raar, S. Sofocleous, \& T. Ravlic, Eds.). Milton, Qld: John Wiley \& Sons Australia. Retrieved from http://catalogue.nla.gov.au/Record/3911801

17. Elfeky, Mostafa I. (2017). The Extent of Voluntary Disclosure and Its Determinants in Emerging Markets: Evidence from Egypt. The Journal of Finance and Data Science, 3(14), 45-59. http://doi.org/10.1016/j.jfds.2017.09.005

18. Eng \& Mak, 2003 Eng, L. L., \& Mak, Y. T. (2003). Corporate Governance and Voluntary Disclosure. Journal of Accounting and Public Policy, 22(4), 325-345. http://doi.org/10.1016/S0278-4254(03)00037-1

19. Freeman, R. E., \& McVea, J. (2001). A Stakeholder Approach to Strategic Management. Darden Business School Working Paper No. 01-02. Retrieved from http://www.ssrn.com/abstract=263511

20. Galani, D., Alexandridis, A., \& Stavropoulos, A. (2011). The Association between the Firm Characteristics and Corporate Mandatory Disclosure the Case of Greece. International Journal of Social, Management, Economics and Business Engineering, 5(5), 1048-1054

21. Gao, L., \& Kling, G. (2012). The Impact of Corporate Governance and External Audit on Compliance to Mandatory Disclosure Requirements in China. Journal of International Accounting, Auditing and Taxation, 21(1), 17-31. http://doi.org/10.1016/j.intaccaudtax.2012.01.002

22. Gitman, L. J. (2000). Principles of Managerial Finance: Brief. Addison-Wesley Longman, Incorporated

23. Gray, R., Kouhy, R., \& Lavers, S. (1995). Corporate Social and Environmental Reporting - A Review of the Literature and a Longitudinal Study of UK Disclosure. Accounting, $\begin{array}{lllll}\text { Auditing } \quad \text { \& } \quad \text { Accountability } & \text { Journal, } & \text { 47-77, }\end{array}$ 
http://doi.org/10.1108/09513579510146996

24. Hakim, S., \& Rashidian, M. (2002). Risk \& Return of Islamic Stock Market Indexes. In 9th Economic Research Forum Annual Meetings Sharjah UAE (pp. 26-28). Retrieved from http://www.iefpedia.com/english/wp-content/uploads/2009/09/Risk-Return-of-IslamicStock-Market-Indexes.pdf

25. Hameed, S., Wirman, A., Alrazi, B., Nazli, M. B. M. N., \& Pramono, S. (2003). Alternative Disclosure \& Performance Measures For Islamic Banks. International Islamic University Malaysia Department Of Accounting. Kuala Lumpur, Malaysia.

26. Hameed, S., Wirman, A., Alrazi, B., Nazli, M., \& Pramono, S. (2004). Alternative Disclosure and Performance Measures for Islamic Banks. Second Conference on Administrative Sciences: Meeting the Challenges of the Globalization Age, King Fahd University of Petroleum \& Minerals, Dhahran, Saudi Arabia, 19-21. http://doi.org/10.1017/CBO9781107415324.004Hameed et al. (2003)

27. Hossain, M., \& Hammami, H. (2009). Voluntary Disclosure in the Annual Reports of an Emerging Country: The Case of Qatar. Advances in Accounting, 25(2), 255-265. http://doi.org/10.1016/j.adiac.2009.08.002

28. Hossain, M., Islam, K., \& Andrew, J. (2006). Corporate Social and Environmental Disclosure in Developing Countries: Evidence from Bangladesh. In Asian Pacific Conference on International Accounting Issues (p. 24). Hawaii. Retrieved from http://ro.uow.edu.au/

29. Hossain, M., Marks, B. R., \& Mitra, S. (2006). Stock Ownership Structure and Voluntary Disclosure of Quarterly Foreign Sales Data of U.S. Multinational Corporations. Multinational Business Review, 14(3), 71. Retrieved from http://connection.ebscohost.com/c/articles/31501636/stock-ownership-structurevoluntary-disclosure-quarterly-foreign-sales-data-u-s-multinational-corporations

30. Ikpor, I. M., Awa, F. N., \& M., O. B. (2016). Board Composition, Firm Size, Audit Type and Voluntary Disclosure of Forward Looking Information in the Banking Sector: Evidence from Nigeria. Research Journal of Finance and Accounting, 7(17), 23-29

31. Iturriaga, F. J. L., \& Sanz, J. A. R. (2001). Ownership Structure, Corporate Value and Firm Investment: A Simultaneous Equations Analysis of Spanish Companies. Journal of Management \& Governance, 5(2), 179-204

32. Jain, B. A., Shekhar, C., \& Torbey, V. (2003). Determinants of Dividend Initiation by IPO Issuing Firms. Journal of Bankinng and Finance, 23, 1-31

33. Jensen, M., \& Meckling, W. (1976). Theory of the Firm: Managerial Behaviour, Agency Costs, and Ownership Structure. Journal of Financial Economics, 305-360

34. Kamla, R., Galhofer, S., \& Haslam, J. (2006). Islam, Nature and Accounting: Islamic Principles and the Notion off Accounting for Environment. Accounting Forum, 30, 245265

35. Khan, F. N., Niazi, G. S. K., \& Akram, T. (2013). Impact of Capital Structure on Firm Financial Performance: A Case Of The Pakistani Engineering Firms Listed On KSE. International Journal of Information, Business and Management, 5(2), 218-241

36. Khanam, F., Nasreen, S., \& Pirzada, S. S. (2014). Impact of Capital Structure on Firm 's Financial Performance: Evidence from Food Sector of Pakistan. Reserach Journal of Finance and Accounting, 5(11), 93-105. http://doi.org/10.5296/ijld.v4i2.5511

37. Kolsi, M. C. (2012). The Determinants of Corporate Voluntary Disclosure: Evidence from the Tunisian Capital Market. IUP Journal of Accounting Research and Audit Practices, 11(4), 49-68. Retrieved from http://search.ebscohost.com/login. aspx?direct=true\&db=bth\&AN=83453355\&site=edslive

38. Lucyanda, J., \& Siagian, L. G. (2012). The Influence of Company Characteristics Toward Corporate Social Responsibility Disclosure. In The 2012 International Conference on Business and Management (pp. 601-619). Phuket, Thailand

39. Maier, S. (2005). How Global is Good Corporate Governance? Ethical Investment Research Services (EIRIS) Ltd. Retrieved from http://www.eiris.org/files/research publications/howglobalisgoodcorpgov05.pdf 
40. Marobhe, M. I. (2014). The Influence of Capital Structure on the Performance of Manufacturing Companies: Empirical Evidence from Listed Companies in East Africa. Research Journal of Finance and Accounting, 5(4), 92-100

41. Messier, W. F., Glover, S. M., \& Prawitt, D. F. (2006). Auditing \& Assurance Services: A Systematic Approach

42. Mollah, A. S., Kevin, K., \& Helen, S. (2000). The Influence of Agency Cost on Dividend Policy in Emerging Market: Evidence from the Dhaka Stock Exchange. The Financial Review, November, 523-547

43. Morris, R. D. (1987). Signalling, Agency Theory and Accounting Policy Choice. Accounting and Business Research, 18(4), 47-56

44. Myers, Stewart C. 1984. "The Capital Structure Puzzle." The Journal of Finance 39(3): 574-92. http://doi.wiley.com/10.1111/j.1540-6261.1984.tb03646.x (July 1, 2019).

45. Ning Chen, R. (2009). Regulation Fair Disclosure and Capital Structure

46. Nguyen, L. S., Tran, M. D., Nguyen, T. X. H., \& Le, Q. H. (2017). Factors Affecting Disclosure Levels of Environmental Accounting Information: The Case of Vietnam. Accounting and Finance Research, 6(4), 255. http://doi.org/10.5430/afr.v6n4p255

47. Owusu-ansah, S. (1998). The Impact of Corporate Attributes on the Extent of Mandatory Disclosure and Reporting by Listed Companies in Zimbabwe. The International Journal of Accounting, 33(5), 605-631

48. Rahman, A. A. A. (2017). The Relationship between Solvency Ratios and Profitability Ratios: Analytical Study in Food Industrial Companies listed in Amman Bursa. International Journal of Economics and Financial Issues, 7(2), 86-93. Retrieved from http://www.econjournals.com/index.php/ijefi/article/view/3960/pdf

49. Raithatha, M., \& Bapat, V. (2014). Impact of Corporate Governance on Financial Disclosures: Evidence from India. Corporate Ownership and Control, 12(1), 874-889

50. Riyanto, B. (2001). Dasar-dasar Pembelanjaan Perusahaan (edisi 4). Yogyakarta: BPFE

51. Ross, S. A. (1977). The Determination of Financial Structure: The Incentive Signalling Approach. Bell Journal of Economics, 8(1), 23-40. Retrieved from http://www.jstor.org/stable/3003485

52. Samaha, K. (2010). Do Board Independence and Audit Committees Motivate Disclosure on Different Corporate Governance Information Categories in the Annual Reports in Developing Countries? International Research Journal of Finance and Economics, (57), 206-224. Retrieved from http://www.eurojournals.com/finance.htm

53. Samaha, K., Dahawy, K., Hussainey, K., \& Stapleton, P. (2012). The Extent of Corporate Governance Disclosure and Its Determinants in a Developing Market: The Case of Egypt. Advances in Accounting, 28(1), 168-178. http://doi.org/10.1016/j.adiac.2011.12.001

54. Semper, D. C., \& Beltrán, J. M. T. (2014). Risk Disclosure and Cost of Equity: The Spanish Case. Contaduria y Administración, 59(4), 105-135. http://doi.org/10.1016/S0186-1042(14)70157-3

55. Sepasi, S., Kazempour, M., \& Mansourlakoraj, R. (2016). Ownership Structure and Disclosure Quality: Case of Iran. In Procedia Economics and Finance (Vol. 36, pp. 108112). Elsevier B.V. http://doi.org/10.1016/S2212-5671(16)30021-1

56. Shen, M.-J., Hsu, C.-C., \& Chen, M.-C. (2006). A Study of Ownership Structures and Firm Values Under Corporate Governance -- The Case of Listed and OTC Companies in Taiwan's Finance Industry. The Journal of American Academy of Business, Cambridge, 8(1), 184-191. Retrieved from http://www.jaabc.com/jaabcv8n1 preview.html

57. Singarimbun, M., \& Effendi, S. (2011). Metode Penelitian Survey (Edisi Revi). Jakarta: LP3ES

58. Soliman, M. M. (2013). Firm Characteristics and the Extent of Voluntary Disclosure: The Case of Egypt. Research Journal of Finance and Accounting, 4(17), 71-80. Retrieved from http://ssrn.com/abstract=2361905

59. Solimun. (2013). Penguatan Metodologi Penelitian Generalized Structured Component Analysis (GSCA). Malang: Program Studi Statistika FMIPA Universitas Brawijaya

60. Suta, I. P. G. A. (2000). Menuju Pasar Modal Modern (Vol. Cetakan 1). Jakarta: Yayasan SAD Satria Bhakti 
61. Talpur, S., Lizam, M., \& Keerio, N. (2018). Determining Firm Characteristics and the Level of Voluntary Corporate Governance Disclosures among Malaysian listed Property Companies. In MATEC Web of Conferences (Vol. 150). http://doi.org/10.1051/matecconf/201815005010

62. Titman, S., \& Wessels, R. (1988). The Determinants of Capital Structure Choice. The Journal of Finance, 43(1), 1-19. http://doi.org/10.1111/j.1540-6261.1988.tb02585.x

63. Van Horne, J. C., \& Wachowicz, J. M. (1997). Prinsip - Prinsip Manajemen Keuangan, Buku Satu (Vol. 9). Jakarta: Salemba Empat

64. Wallace, R. S. O., Naser, K., \& Mora, A. (1994). The Relationship between the Comprehensiveness of Corporate Annual Reports and Firm Characteristics in Spain. Accounting and Business Research, 25(97), 41-53

65. Wallace, P., \& Zinkin, J. (2005). Corporate Governance in the Mastering Business In Asia. Singapore: John Willey \& Sons. Retrieved from http://as.wiley.com/WileyCDA/WileyTitle/productCd-0470821124.html\#

66. Watson, A., \& Marston, C. (2002). Voluntary Disclosure of Accounting Ratios in the UK, 8389(August). http://doi.org/10.1006/S0890-8389(02)00077-X 